\title{
OBITUARY
}

\section{Renato Contin Marinoni (26.III.1939 - 29.VI.2011)}

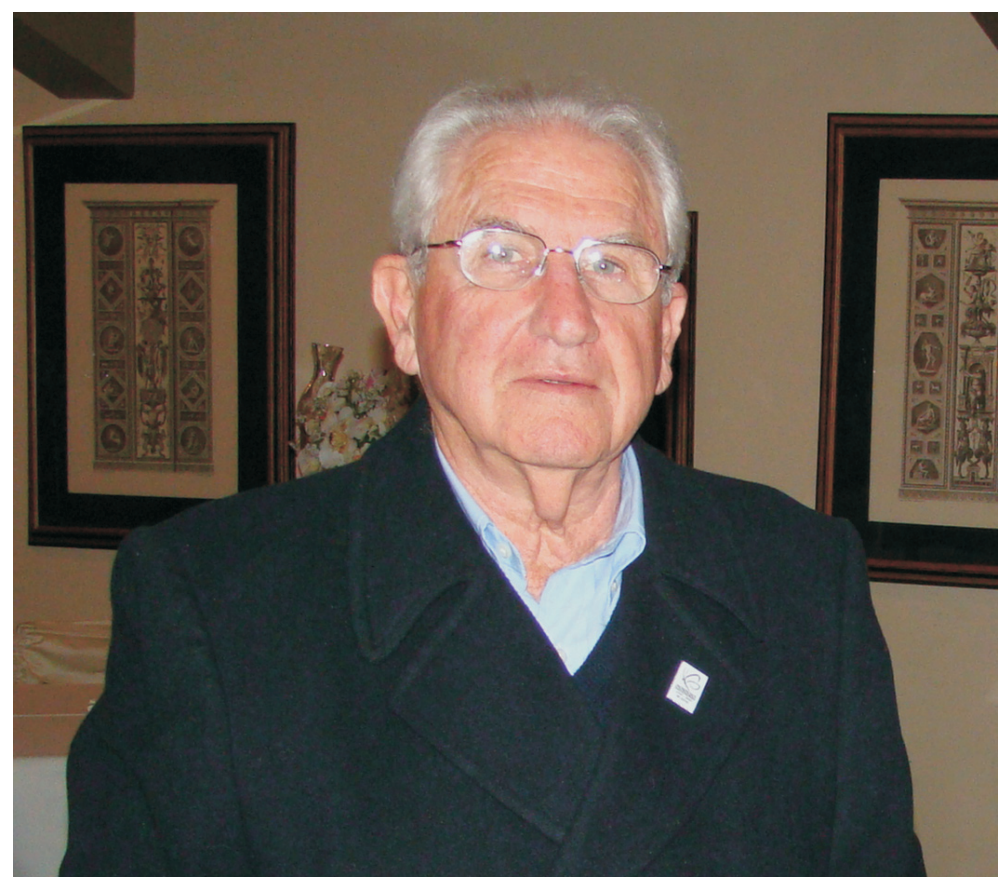

Renato Contin Marinoni, Curitiba, PR, August 2009.

An obituary, although written at a sad time, pays honor and respect to a dear family member, friend, and colleague. It is difficult to summarize the many accomplishments of Renato Contin Marinoni. He very closely followed the poet's observation "life is too short to be small." Renato (as we all called him) did not seek personal recognition. He "wore the uniform of his team". His commitments were firm, and closely following his devotion to family was his commitment to foster the Department of Zoology of the Universidade Federal do Paraná (UFPR).

During his almost 50 years of professional life, Renato Contin Marinoni played a pivotal role in transforming the Department of Zoology into a renowned research center. His performance as an administrator and professor was always impeccable and constructive, leaving a profound and an indelible mark on his home institution. Renato was often viewed as a reserved, serious person by those who did not know him well. This superficial, first impression kept some students and professors at a distance. Those close to him, however, knew a quite different, friendly, open-hearted man. From a taxonomist's point of view, the latter characterizations were his diagnostic features, and they will never be forgotten. 
Renato joined the Department of Zoology shortly before he graduated (1962) in Natural History from the Faculty of Philosophy, Sciences and Letters of the UFPR. At that time, Father Jesus Santiago Moure, the founder and chairman of the Department, was a full or "cathedratic" professor there. His position enabled him to hire, suggest for nomination, or nominate university employees. Fr. Moure hired Renato as an instructor (without ties to the institution) to help Prof. Dr. Hans Jakobi at the animal physiology laboratory, which was then part of the Zoology Department. Hans Jacobi worked on Copepods (Crustacea), and probably for that reason, Renato developed an interest on the taxonomy of the group that resulted in a few publications.

In the early1960's the Department of Zoology was still small, having no more than six faculty members. The addition of Renato brought some enthusiasm to the team, even though he was just an instructor. As a student, Renato had some earlier experience working at the State Bank of Paraná and he soon became Fr. Moure's right hand man. He took on administrative tasks, such as accounting and report writings that had formerly been done by the department's chairman. Then, the department's insect collection was very small, numbering only a few hundred unidentified specimens stored in old cabinets. Renato took the first steps towards organizing the collection. First, he supervised the construction of the standard cabinets and drawers with glass tops that are still in use by the department; second, he purchased private insect collections with grant money and incorporated them into the department's collection. At some point, Renato gave up his research on CopepodaCrustacea and started dedicating his time to the study of Coleoptera, focusing on Cerambycidae.

In 1966, the Brazilian government created a Teaching Certification in the Sciences, Mathematics, Physics and Chemistry, to be implemented by universities. The Department of Zoology (UFPR) became responsible for granting a Teaching Certificate in the Sciences. In order to accommodate the new teaching requirement, the department chairman opened two contractual teaching positions. Renato C. Marinoni was hired for one of them, joining the faculty of the Universidade Federal do Paraná. Several years later (1972) Renato was finally hired on a tenure-track position, as an Assistant Professor, and was soon promoted to Adjunct Professor (1972). Working fulltime for the University, Renato taught various disciplines in the department's graduate program in Entomology, Zoology and Botany. He also continued to teach for the Teaching Certification program and the School of Medicine. Renato advised over 40 undergraduate, Masters' and Ph.D. students in taxonomy, ecology, biodiversity and faunistic studies. He used to joke, saying that a good taxonomist needs to be good at the "game of seven errors."

The University Education Reform of 1968, implemented by the government, brought about the opportunity to create graduate programs in various departments. Fr. Moure quickly

ZOOLOGIA 28 (6): 831-836, December, 2011 
embraced the prospect and assembled a faculty committee to formulate a proposal. Renato soon became the committee's coordinator because of his leadership skills and ability to make fast, objective decisions. Within a very short time, the faculty members produced a full proposal, which was forwarded to the Federal Council of Education, Brasília-DF.

In 1969 the CNPq recognized the Department of Zoology of the UFPR as a centre of excellence in entomology. This recognition allowed the dean to sanction the graduate program, which was then called the "Masters Program in Entomology and Human Genetics." Renato was one of the first ten students to enroll, and he was also the first one to graduate in 1971. In 1978, he took a one-year leave to work on his Ph.D. thesis under Dr. Ubirajara R. Martins de Souza advisory, at the Museu de Zoologia-USP, São Paulo. One year late, Renato finished his Ph.D. studies and, again, he was the first one to graduate and earn his doctorate (1979).

As a result of the University's Education Reform, the University Cathedra, as well as the Faculty of Philosophy, Sciences and Letters of the UFPR became extinct in 1972. Additionally, leadership of the Department became an elective process from a list of three candidates. Fr. Moure became Full Professor and was nominated as chairman of the Department and Renato now officially served as vice-chairman.

A man of vision and action, Renato headed several research projects throughout his career, receiving support from various agencies such as CNPq, CAPES, FINEP, UFPR. In 1981 he implemented the Centre for the Identification of Phytophagous Insects (CIIF). The mission of the CIIF, which included entomologists from the Department of Zoology, was to identify pest insects and insects targeted in research projects. It served the needs of students, national and international researchers, and institutions.

In 1986, Renato and collaborators started a survey of the insects of Paraná - PROFAUPAR. Their aim was to conduct extensive collecting in different environments (according to vegetation, climate and altitude) within the state using Malaise and light traps. This survey yielded many specimens for the Coleção Entomológica Padre Jesus Santiago Moure (DZUP), which is internationally recognized. Together with the Centre for the Identification of Phytophagous Insects, this initiative opened up opportunities for hiring and training, and provided material and data for numerous Masters dissertations, Ph.D. theses and publications by national and foreign researchers. Additionally, Renato managed the Department's activities on the CNPq project Polonoroeste, from 1981 to 1984. More recently (1999-2002), he coordinated the PROVIVE, an insect survey project similar to PROFAUPAR, but restricted to the Vilha Velha State Park in Ponta Grossa, Paraná.

Owing to his natural ability to lead, his adherence to principles and his professionalism, Renato rapidly became an important figure in the national scientific community. During his career, he served several national institutions in a variety 
of ways, as follows. With CNPq, he helped implement the National Strategy for Zoology - PNZ, was a member of the Zoology Advisory Committee, and a member of the PRONEX's Coordination Committee - Centers of Excellence Program. He served CAPES as a member of various committees, evaluating Graduate Programs in the biological sciences; the Sociedade Brasileira para o Progresso da Ciência in the design of a national plan for biodiversity (Política Nacional de Biodiversidade); and with the Instituto Brasileiro do Meio Ambiente (IBAMA), as a member of the Faunistic Protection Council, organized a group to work on a list of species of animals threatened with extinction in Brazil. Additionally, he actively participated in foundations to foster research from several Brazilian states.

Renato was president of the Sociedade Brasileira de Zoologia (SBZ) from 1988 to1989. During this period, he initiated the process of modernizing and data basing the information of SBZ's members. During those years he also initiated the development of the Directory of Brazilian Taxonomists published in 1996. He also mobilized the zoological community and nominated local representatives, expanding the representation of the SBZ at the national level. Also during his term, he launched the Revista Brasileira de Zoologia (now ZOOLOGIA) as a quarterly journal publication.

Renato received many honors and awards for his collaboration and competence in activities that improved the Department, and zoological sciences at the national level.

A man of enviable knowledge, Renato was always open to new paths, and would easily get bored with tasks that did not pose a challenge. Two projects of recent interest were first, to understand the contribution of molecular biology to taxonomy; and second, to create and make available to the scientific community, a database including the Cerambycidae types photographed by Fr. Moure during his visits to European and American museums, and the types deposited in the Entomological Collection of the Department of Zoology. This database will be different from its counterparts and will contain an innovation from Renato. Currently, researchers working for the Taxonline - Biological Collection Network of Paraná, are finishing this project.

Besides being a competent professional, Renato was a marvelous human being and a good companion. In 1958, he met and fell in love with Dona Neuza, whom he married and started a harmonious family with. Though devoted to his family, his love for his daughters Luciane, Andrea and Patricia sometimes had an overly protective, unusual slant. For instance, the girls were never allowed to have a bike! In the 1990's Renato became a grandfather. Equally passionate about his two granddaughters, Giovana and Renata, but without the burdens and responsibilities of a parent, he accompanied them in travels and tours, including several adventures on rollers coasters in Orlando, Florida.

Renato was also very devoted to his friends. He was fond

ZOOLOGIA 28 (6): 831-836, December, 2011 


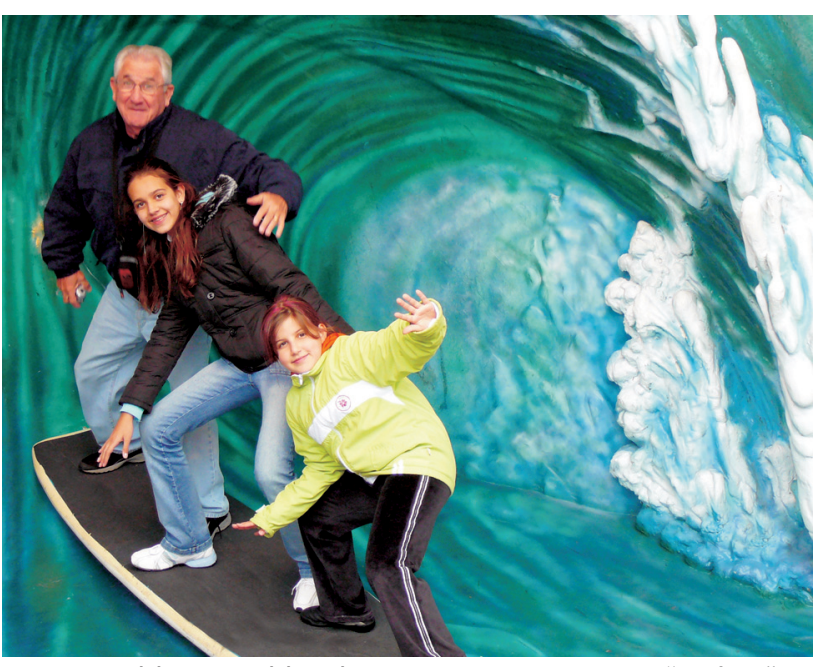

Renato and his granddaughters, Renata e Giovana, "surfing" at Universal Studios City Walk, Orlando, FL.

of gatherings and enjoyed a good meal and pleasant conversation. During gatherings he often showed his humorous, playful side. Caring, he rejoiced in the achievements of his peers, and when times were difficult for them, Renato tried to listen and offer help. Always ready to assist others, he would spend enormous amounts of time trying to answer research questions, or even Googling for friends' on how to get to Barigui Park, where he walked in the mornings.

If we could to define Renato with only one word, this word would be INTEGRITY! Renato's actions and activities are registered in every corner of the zoology department. His emblematic figure is forever in ours hearts.

\section{Testimonials}

My first encounter with Renato, back in 1969, was quite peculiar. Father Jesus S. Moure had advised him to discuss with me whether his master's project, a revision of the genus Tapeina, was appropriate. Because he had commitments at the University, he could only come to São Paulo on a weekend. At the time I used to go to my farm in Itu every weekend, and he agreed to go meet me there. Renato came from Curitiba all the way to Itu. We meet, discussed the topic of his thesis, and became very good friends.

I was a member of his thesis committee together with H.J. Reichardt and J.S. Moure. When he decided to do a Ph.D., he was awarded a year scholarship to work with me at the Museu de Zoologia. His project, a comparative study of the anatomy of the type species of the genera of Lamiinae, was complicated, and required a great deal of time and dedication. Every evening we discussed his progress and addressed matters related to zoology. From that time on we maintained an active correspon- 
dence, in which we often discussed our worries regarding the fate of zoology in Brazil.

I have lost a great and dear friend; collectively, Zoology has lost an exponent.

Ubirajara R. Martins - Museu de Zoologia (MZUSP), São Paulo, SP

I had my first contacts with Renato through correspondence when I was in Uruguay. It must have been in 1964 or 1965. We traded Cerambycidae specimens and exchanged information. In 1968, during a trip to Brazil, I had the opportunity to meet him. From that point on, Renato and I became friends. Right in the beginning of his doctoral work, Renato faced a new problem, the definition of the type-genus and typespecies of the Neotropical Cerambycidae tribes. He then published one of the first contributions on Cerambycidae nomenclature and encouraged me to compile and publish a catalog of the Neotropical Cerambycidae. I was a member of his dissertation committee, along with Ubirajara Martins. Renato defended his Ph.D. after working very hard on the anatomy of the type-species of the genera that give name to the Lamiinae tribes.

As the years passed, our friendship grew stronger. There were also times when my contact with Renato was restricted to our joint participation in dissertation committees. During our careers, our research focus diverged. While Renato worked on large and ambitious zoogeographical and faunal surveys, I continued to work on the systematics of Cerambycidae. Instead of separating us, however, our different research goals fostered an exchange of ideas and information which was intense and fruitful.

A good friend is gone leaving, a void that cannot be filled. Thank you for your friendship, my dear "Renatão".

Miguel A. Monné - Museu Nacional (MNRJ), Rio de Janeiro, RJ

\section{Albino M. Sakakibara; Dilma Solange Napp \& Sionei R. Bonatto}

Departamento de Zoologia, Universidade Federal do Paraná. Caixa Postal 19020, 81531-980 Curitiba, PR, Brazil. 